\section{3}

Key Biscayne, Fla.

Williamsburg, Va.

Harwichport, Mass.

Denver, Colo.

Salt Lake City, Utah

Mexico City, Mexico

Boulder, Colo.

London, Ontario

Montreal, P.Q.

Fairbanks, Alaska

Ft. Collins, Colo.

Kyoto, Japan

Leningrad, USSR

Monterey, Calif.

Tashkent, USSR

Nice, France

Baku, USSR

Denver, Colo.

Boulder, Colo.

Washington, D.C.

San Francisco, Calif.

Honolulu, Hawaii

Melbourne, Australia

Nairobi, Kenya

San Francisco, Calif.

St. Louis, Mo.

Lake Tahoe, Calif.

Washington, D.C.

Lincoln, Nebr.

Santa Barbara, Calif.

Atlanta, Ga.

Tucson, Ariz.

El Paso, Tex.

Ft. Lauderdale or

Miami, Fla.

\section{May 14-17 \\ June 4-6 \\ June 9-10 \\ June 11-13}

June 11-15

June 17-July 7

June 19-22

June 26-28

July 17-19

Aug. 15-17

Aug. 22-24

Sept. 9-21

Sept. 23-29

Oct. 1-4

Oct. 1-7

Oct. 4-10

Oct. 8-15

Oct. 15-17

Oct. 18-19

Dec. 10-12

Dec. 10-14

1974

Jan. 8-11

Jan. 14-25

Jan. 31-Feb. 6

Feb. 25-Mar. 2

Mar. 4-7

April

April 8-12

April 17-19

Sept. 9-13

Sept./Oct.

October

November

November
Eighth Conference on Hurricanes and Tropical Meteorology

Fifth Conference on Laser Radar Studies of the Atmosphere

Fifth Conference on Weathercasting (Radio and TV)

AIAA/AMS International Conference on the Environmental Impact of Aerospace Operations in the High Atmosphere

With Pacific Division of the AAAS

Joint Meeting of the AAAS and the Mexican Consejo Nacional de Ciencia y Technologia

Third Conference on Probability and Statistics in Atmospheric Science Second Conference on Electrostatics with the Electrostatics Society of America

1973 Summer Computer Simulation Conference

Climate of the Arctic with the AAAS Twenty-Fourth Alaskan Science Conference

With 1973 ASCE Irrigation and Drainage Division Specialty Conference Second General Scientific Assembly of the International Association of Geomagnetism and Aeronomy (IAGA)

Eighth International Conference on Nucleation of the IAMAP (ICCP) Second Conference on Numerical Prediction

International Conference on Weather Modification of the WMO and IAMAP

International Symposium on the Chemistry of Sea/Air Particulate Exchange Processes

XXIV International Astronautical Federation Congress

Eighth Conference on Severe Local Storms

Symposium on Cumulus Modelling

Second Conference on Sensing of Environmental Pollutants with ISA,

IEEE, ACS, AIAA, NOAA, NASA, EPA, DOT

With the AGU Fall Annual Meeting

54th AMS Annual Meeting

First Special Assembly of the International Association of Meteorology and Atmospheric Physics (IAMAP) and the Scientific Assembly of the International Association of Physical Sciences of the Oceans (IAPSO) International Tropical Meteorology Meeting

With the Annual Meeting of the AAAS

Fifth Conference on Weather Forecasting and Analysis

Third Joint Conference on Fire and Forest Meteorology with the Society of American Foresters (SAF)

With AGU Annual Meeting

International Livestock Environment Symposium of the ASAE

Symposium on Atmospheric Diffusion and Air Pollution

Conference on the Upper Atmosphere

National Conference on Cloud Physics

Sixth Conference on Aerospace Meteorology

Fourth Conference on Weather Modification 


\section{Call for Papers}

\section{Fifth Conference on Laser Radar Studies of the Atmosphere, June 4-6, 1973, Williamsburg, Va.}

The Fifth Conference on Laser Radar Studies of the Atmosphere will be held at the Hilton Inn in Williamsburg, Virginia, under the sponsorship of the Group on Laser Atmospheric Probing and the American Meteorological Society in cooperation with the Optical Society of America, and hosted by the National Aeronautics and Space Administration's Langley Research Center on June 4-6, 1973.

The Chairman of the Program Committee: S. H. Melfi, NASA Langley Research Center, Mail Stop 401A, Hampton, Va. 23365.

\section{Fifth Conference on Weathercasting (Radio and TV) June 9-10, 1973, Harwichport (Cape Cod), Mass.}

The Fifth Conference on Weathercasting of the American Meteorological Society will be held at the Wychmere Harbor Club in Harwichport, Mass, on Saturday, June 9, and Sunday, June 10, 1973. The program was published in the April BULLETIN.

\section{AIAA/AMS International Conference on the Environmental Impact of Aerospace Operations in the High Atmosphere, June 11-13, 1973, Denver, Colo.}

The International Conference on the Environmental Impact of Aerospace Operations in the High Atmosphere will be held at Brown Palace Hotel in Denver, Colo., June 11-13, 1973. The conference, which is co-sponsored by the AIAA and the AMS, has been initiated to provide a timely, open, and significant forum for the publication and discussion of information relevant to the environmental impact of aerospace activity in the stratosphere.

Conference Program Co-chairmen: Dr. Julius London, Department of Astrogeophysics, University of Colorado, Boulder, Colo. 80302 and Dr. M. H. Bortner, General Electric Company, P.O. Box 8555, Philadelphia, Pa. 19101.

The Conference General Chairman, to whom inquiries may be directed is Dr. R. T. H. Collis, Stanford Research Institute, Menlo Park, Calif. 94025. The program was published in the March Bulletin.

\section{Annual Meeting of the Pacific Division of the American Association for the Advancement of Science, June 11-15, 1973, Salt Lake City, Utah}

The Pacific Division of the AAAS will hold its annual meeting, June 11-15, 1973 in Salt Lake City, Utah. The American Meteorological Society will cosponsor a one-day symposium (invited) on Use of Meteorology in the Preservation and Improvement of Air and Water Quality to be held on June 12 at the University of Utah.

The program will consist of the following papers: The role of a meteorologist in the Environmental Protection Agency (D. Henderson); Surface mesoscale wind flow during a low visibility-ventilation episode in the Salt Lake Valley (C. Bower and D. Shearer); Diffusion in a canyon within rough mountainous terrain (G. Start, C. Dickson, and L. Wendell); The usefulness of official Salt Lake City data for estimating ventilation conditions over outlying intermountain valleys (G. Reynolds); Monitoring atmospheric stability with an acoustic sounder ( $F$. Hall); The role of the industrial meteorologist in air pollution problems (Staff, Kennecott Copper Corp.); A 30-year comparison between the automobile and copper smelting relative to air pollution (W. Chapman); and an Open Forum on use of meteorology in air pollution control.

For information contact: Robert M. Black, Chairman, AMS Uiah Chapter, c/o Western Regional Headquarters, National Weather Service, P.O. Box 11188, Federal Building, Salt Lake City, Utah 84111.

\section{Third Conference on Probability and Statistics in Atmospheric Science, June 19-22, 1973, Boulder, Colo.}

The American Meteorological Society's Third Conference on Probability and Statistics in Atmospheric Science will be held in Boulder, Colo., June 19-22, 1973. The conference is being organized by the AMS's Committee on Probability and Statistics.

The Program Chairman is Allan H. Murphy, Probability and Statistics Conference, National Center for Atmospheric Research, P.O. Box 1470, Boulder, Colo. 80302. The program was published in the March Bulletin.

\section{Second Conference on Electrostatics, June 26-28, 1973, London, Ontario, Canada}

The Second Conference on Electrostatics jointly sponsored by the American Meteorological Society and Electrostatics Society of America will be held June 26-28, 1973 at the University of Western Ontario, London, Ontario, Canada.

The program includes the following sessions: ions, aerosols, and the biosphere; nuisances and hazards; trends in certain areas; and new developments.

The program was published on page 280 of the March BuLleTin.

\section{Summer Computer Simulation Conference, June 17-19, 1973, Montreal, Quebec, Canada}

The 1973 Summer Computer Simulation Conference will be held July 17-19, 1973 at the Queen Elizabeth Hotel, Montreal, Canada. The American Meteorological Society together with AIChE, ISA, SCI, and SHARE will cosponsor this conference.

The theme of the conference is Simulation-Increasing its Credibility. Papers were solicited on the following topical areas: 1) validation of simulation models; 2) language and tools; 3) applications; 4) physical sciences; 5) chemical sciences; 6) earth sciences; 7) life sciences; 8) social sciences.

The program Chairman is: Dr. Richard J. Sylvester, General Research Corporation, P.O. Box 417, Denville, New Jersey 07831 (tel: 201-627-3600). Program outline is published on page 492.

\section{Call for Papers}

Twenty-Fourth Alaskan Science Conference on the Climate of the Arctic, Jointly with AAAS, August 15-17, 1973, Fairbanks, Alaska

The 24th Alaskan Science Conference, to be held at the University of Alaska in Fairbanks, Alaska, from August 15-17, 1973, has as its theme the Climate of the Arctic. It will be 
held under the joint sponsorships of the AAAS and the AMS. Papers will deal with basic climate studies and the implications of climate on the polar regions such as biological effects and consequences to man. The following topics will be considered: 1) Climatology-past, present and future climates; Man-made climate modifications; International large-scale studies (GARP, POLEX, AIDJEX), 2) Climate and its biological effects-Plant and animal responses, adaptations and interactions; Resources and ecosystem studies, and 3) Climate and man-Agriculture; energy, cities and houses; transportation; health and leisure. Papers are solicited on all aspects of climate in the polar regions, especially those of a broad review and/or interdisciplinary nature (relating meteorology to the physical, biological and social sciences as well as to engineering, transportation and other aspects of life in the Arctic). Titles are requested by 1 June, abstracts (330-600 words) by 1 July. The Conference Chairman is Dr. Gunter E. Weller, Geophysical Institute, University of Alaska.

Registration will begin on Tuesday, Aug. 14 at 2:00-6:00 p.m. and will continue on Wednesday at 8:00 a.m. Technical sessions will be held Wednesday through Friday from 9:00 a.m.-5:00 p.m. with Luncheon scheduled on Wednesday and Thursday. Social events for families and friends will be arranged. Post-conference excursions are planned for Saturday and Sunday to include the North Slope, Cook Inlet and Mt. McKinley.

Arrangements can be made for those wishing to stay in Bartlett Hall, a modern dormitory on campus (walking distance to meeting places). Guests will pay $\$ 7$ per person (double room); \$11 single room. Meals can be taken in the cafeterias and dining halls of the University. Typical rates at hotels and motels in downtown Fairbanks (approx. 6 miles away) are \$20-28 single and \$24-33 double. Rental cars are available at Fairbanks airport; cab fares to the University are approx. \$5-6.

Abstracts, inquiries, and registration (\$15) should be directed to the Director, Geophysical Institute, University of Alakka, Fairbanks, Alaska 99701; (tel: 907-479-7282).

\section{ASCE Irrigation and Drainage Division Specialty Conference, August 22-24, 1973, Ft. Collins, Colo.}

The American Meteorological Society will cosponsor the 1973 ASCE Irrigation and Drainage Division Specialty Conference, August 22-24, 1973 at the Colorado State University Campus, Ft. Collins, Colo. The Soil and Water Division of the American Society of Agricultural Engineers will cooperate in this meeting.

The conference will combine a broad coverage of interesting and timely papers covering every phase of irrigation and drainage technology with a delightful family vacation in the Colorado Rockies. The theme of the meeting is agricultural and urban considerations in irrigation and drainage.

For complete information, write to: Dr. Maurice L. Albertcon, Department of Civil Engineering, Colorado State University, Ft. Collins, Colo. 80521 or Ray J. Winger, Jr., 4050 Ammons St., Wheat Ridge, Colo. 80033.

\section{8th International Conference on Nucleation of IAMAP, September 23-29, 1973, Leningrad, USSR}

The 8th International Conference on Nucleation sponsored by the International Committee on Cloud Physics of the International Association of Meteorology and Atmospheric
Physics of the IUGG and the USSR National Committee of Geophysics will be held at the Scientists Club in Leningrad. The day of arrival is September 23rd and the meeting will be held september 24-29, 1973.

The following topics will be included: a) nucleation mechanisms, b) methods and results of natural measurements of ice nuclei, and c) nuclei in processes of cloud formations in real (contaminated) atmosphere.

Abstracts of 300 words (English or Russian) are due prior to 1 May 1973 and should be sent to Prof. I. I. Gayvoronsky, Head, Weather Modification Dept., Central Aerological Observatory, Moscow, USSR with a copy to Prof. H. W. Georgii, Inst. f. Met. u Geophysik, Feldberstrasse 47, 6000 Frankfurt am Main, West Germany. The President of ICCP and U.S. contact is Dr. Helmut K. Weikmann, 603 Wewoka Dr., Boulder, Colo. 80303.

\section{Call for Papers}

\section{Second Conference on Numerical Prediction, October 1-4, 1973, Monterey, Calif.}

A National Conference on Numerical Prediction, sponsored by the American Meteorological Society will be held at the Naval Postgraduate School, Monterey, Calif., October 1-4, 1973.

The theme of this conference is the numerical prediction of various meteorological and oceanographic phenomena over a variety of time periods. Papers are invited in the following interrelated topic areas: basic dynamics, numerical methods, ocean circulation and air-mass interaction models, general circulation and long range prediction models, tropical models, mesoscale and small scale models, parameterization of latent heat release, predictability and stochastic models, and initialization and time-space assimilation. It is suggested that papers on the verification of forecasting models may be more appropriate for the Weather Forecasting Conference in St. Louis in March 1974.

The Naval Postgraduate School together with the Monterey Peninsula Chapter of the AMS, will be hosting this meeting. The Program Committee includes R. T. Williams (Chairman), Akio Arakawa, Russell Elsberry, Celia Barteau, and Thomas Baxter. Titles and abstracts should be submitted before 20 May 1973 to Prof. R. T. Williams, Code $51 \mathrm{Wu}$, Naval Postgraduate School, Monterey, Calif. 93940.

\section{International Conference on Weather Modification of WMO and IAMAP, October 1-7, 1973, Tashkent, USSR}

The International Conference on Weather Modification sponsored by the World Meteorological Organization and the International Association of Meteorology and Atmospheric Physics and hosted by the USSR's Hydrometeorological Service will be held October $1-7,1973$ in Tashkent, USSR.

Survey papers should serve for general information as to the state of knowledge, whereas selected contributed papers should be focused on the most recent advances in the practical possibilities of weather modification. Papers on weather modification are solicited on the scientific concepts of the different types: description of technical and operational aspects of experiments and scientific evaluation of results; and economic factors.

Abstracts of 300 words should be sent prior to 1 May 1973 to WMO, Secretariat, Case Postale No. 1, CH-1211 Geneva 20, Switzerland with copies to Dr. Roland List, Dept. of Physics, University of Toronto, Toronto 5, Ont., Canada 
and to Dr. Yuri S. Sedunov, 18 Toliot Kurie Str., Institute of Experimental Meteorology, Obninsk Kaluga Region, USSR. Inquiries concerning program, registration, etc. may be sent to the WMO.

\section{Call for Papers}

\section{International Symposium on the Chemistry of Sea/Air Particulate Exchange Processes October 4-10, 1973, Nice, France}

An International Symposium on the Chemistry of Sea/Air Exchange Processes will be held in Nice, France from October 4-10, 1973. This Symposium is sponsored by several French and international organizations interested in environmental problems such as "Ministère de l'Environnement," "Centre National de la Recherche Scientifique," "Délégation Générales à la Recherche Scientifique et Technique," "Direction chargée des Universités et des éstablissements d'enseignement supérieur et de recherche," UNESCO, the International Association for the Physical Sciences of the Ocean of the International Union of Geodesy and Geophysics. The American Meteorological Society will cooperate. It will concentrate on non-gaseous exchange processes occurring across the sea/ air interface and their implications. Topics of particular interest include:

1. Physico-Chemical Properties of the Sea/Air Interface:

Chemistry of sea surface films, organic material at the sea surface, surface tension, the production of aerosols by breaking bubbles, and ionic fractionation.

2. Marine Atmosphere Chemistry:

Chemical composition of marine aerosols with respect to major and trace elements and organic matter, especially petroleum and chlorinated hydrocarbons, relationship between size and chemical composition of aerosols, atmospheric distribution of aerosols.

3. Geochemical Implications:

Discrimination between marine aerosols and continental dust, influence of marine and continental sources on the chemical composition of atmospheric particulates, exchange of particulate matter between ocean continents via the atmosphere, atmospheric fallout on the sea.

4. Environmental, Meteorological, and Pedological Implications:

The problem of the non-polluted baseline, the importance of marine sources to the composition of natural aerosols, influence of sea surface pollution on sea/air exchange rates, marine aerosols as condensation nuclei, the role of marine aerosols on soil fertility.

Organizing committee of the Symposium is as follows:

Roger Chesselet, Jacques Labeyrie and Jacques MorelliCFR-CNRS, 91190, Gif-sur-Yvette, France. Robert A. Duce, Graduate School of Oceanogkaphy, University of Rhode Island, Kingston, R.I. 02881, U.S.A.

Titles and abstracts of submitted papers should be sent to the program chairman, Jacques Morelli, not later than 1 June 1973. Information on the symposium can also be obtained in the United States from Robert A. Duce.

\section{International Astronautical Federation Congress October 8-15, 1973, Baku (USSR)}

The XXIV IAF Congress will be held on October 8-15, 1973, at the Azerbaijan SSR Academy of Sciences; Baku,
USSR. The IAF Committee on Application Satellites (CoChairmen Dr. L. Jaffe and Prof. K. Kondratyev) is organizing within the program of the IAF Congress, two sessions devoted to the problem: Remote sensing of the environment from space.

These sessions are co-sponsored by the COSPAR VI Working Group (Chairman Dr. M. Tepper) and the Radiation Commission of the International Association of Meteorology and Atmospheric Physics (President, Prof. J. London). The American Meteorological Society will cooperate.

The main objective of the sessions is to discuss the contemporary state and future development of remote sensing from space in connection with the problem of interaction between man and the environment. The following topics will be covered: 1. Meteorology, hydrology and oceanology; 2. Atmospheric and sea pollution; 3. Biosphere (agriculture, forestry and marine life); 4. Geology and geomorphology; 5. Test sites and combined subsatellite experiments (including the problem of the atmospheric transfer function); 6. Automatic techniques of data processing (pattern recognition, spectral signatures, etc).

All communications should be directed to Prof. K. Ya. Kondratyev, Institute of Physics, the University, Leningrad B-164, USSR.

Questions of general nature may be addressed to: Mr. G. S. Balayan, Secretary, Commission on Space Research of the USSR Academy of Sciences, Vavilova 32, Moscow B-312, USSR.

\section{Eighth Severe Local Storms Conference, October 15-17, 1973, Denver, Colo.}

The American Meteorological Society will hold its 8ih Severe Local Storms Conference at the New Albany Hotel in Denver, Colorado, October 15-17, 1973 (Monday through Wednesday).

Special emphasis will be given to "The Structure of the Airflow in and Around Severe Convective Storms." Other sections will include "Precipitation-Airflow Relationships," "Tested Criteria for Forecasting Thunderstorm Generation," "Severe Convective Storm Modelling and Scale Interaction," "Climatology of Convective Storms such as Severity, Classes, Terrain Factors, and Urban Influences." There will be no multiple sessions. Preprinting will enable authors to be brief and to emphasize the important points in their work so that ample time remains for discussion. General guidelines will be furnished to participants.

A complete manuscript will be preprinted for the conference for prior distribution so that complete cameraready test, including diagrams must be received by 15 June 1973. Manuscripts must be either 2, 4, 6, but no longer than 8 pages in length. Page charges will be assessed to defray the cost of printing. Instructions and special paper will be furnished to speakers.

Titles and 200-400 word reviewer's abstracts should be sent by 31 March 1973 to J. C. Fankhauser, National Center for Atmospheric Research, Boulder, Colo. 80302. A shorter abstract should also be included for the Program to be published in the Bulletin.

\section{Symposium on Cumulus Modelling October 18-19, 1973, Boulder, Colo.}

The American Meteorological Society in cooperation with NOAA will sponsor a Symposium on Cumulus Modelling 
to be held at the Environmental Research Laboratory, NOAA, Boulder, Colorado, October 18-19.

The conference will deal with various aspects of cumulus modelling, including the interaction of microphysical processes and cumulus dynamics, parameterization of turbulent fluxes, the interaction of synoptic, mesoscale and cumulus scale systems, verification of models, and parameterization of convective fluxes for larger scale models. In order to encourage discussion, the conference will follow a workshop format with papers presented by invitation only. The program chairman is Dr. William Cotton, Experimental Meteorology Laboratory, P.O. Box 8044, University of Miami Branch, Coral Gables, Florida 33124.

The Technical Program Chairman is M. E. Ringebach, Director, Engineering Development Laboratory, NOAA/National Ocean Survey, Rockville, Maryland 20852.

\section{2nd Joint Conference on Sensing of Environmental Pollutants, December 10-12, 1973, Washington, D.C.}

The 2nd Joint Conference on Sensing of Environmental Pollutants will be held December 10-12, 1973 at the Sheraton Park Hotel, Washington, D.C. The sponsoring organizations are: American Chemical Society, American Institute of Aeronautics and Astronautics, American Meteorological Society, Institute of Electrical and Electronic Engineers, Instrument Society of America, Department of Transportation, Environmental Protection Agency, National Aero. nautics and Space Administration, and National Oceanic and Atmospheric Administration.

The theme of the conference is "Sensors are Critical to the Nation's Environmental Get-Well Program," and the objective of the conference is to exchange information concerning the basic phenomenology related to sensors and sensing techniques for measuring land, water, and air environmental quality parameters.

The conference is directed to representatives of all tech nical disciplines concerned with the development, evaluation, and use of pollution measuring techniques. Papers were solicited covering, but not limited to, the following areas: 1) Extending the capability of existing sensors-range of measurement, accuracy, reliability, survivability, etc.; 2) Developing new in situ and remote sensors for measuring those parameters that cannot be measured conveniently under field conditions; 3) Applied research into relatively new techniques of sensing and measuring for field and laboratory applications-bioaccumulator, photographic, chemical, acoustic, semiconductor, electromagnetic, etc.; 4) Establishing data standards to provide for maximum interchangeability and use of data among the various user groupsmonitoring management, prediction, scientific modelling, etc.

\section{Call for Papers}

\section{4th Annual Meeting of the American Meteorological Society, January 8-11, 1974, Honolulu, Hawaii}

The 54th Annual Meeting of the American Meteorological Society will be held in Honolulu, Hawaii, January 8-11, 1974.

The program will probably include some special sessions on invited papers. Papers on topics particularly related to
Pacific meteorological, hydrological and air-sea interaction problems will be welcomed. Anyone wishing to submit a paper for consideration should send a title and definitive abstract (not more than 200 words) to Prof. C. S. Ramage, Department of Meteorology, University of Hawaii, 2525 Correa Road, Honolulu, Hawaii 96822, by 1 August 1973.

\section{Call for Papers}

\section{IAMAP First Special Assembly, January 14-25, 1974, Melbourne, Australia}

The International Association of Meteorology and Atmospheric Physics (IAMAP) of the International Union of Geodesy and Geophysics (IUGG) will hold its First Special Assembly, January 14-25, 1974 in Melbourne, Australia. The First Special Assembly of the Association for the Physical Sciences of the Ocean will be held in conjunction with the IAMAP Assembly. The American Meteorological Society and other organizations will cooperate in these meetings.

An outline of IAMAP symposia follows: 1) Frontiers Sessions, 2) International Conference on the Structure, Composition and General Circulation of the Upper and Lower Atmosphere and Possible Anthropogenic Perturbations, 3) Air-Sea Interaction Symposium, 4) Meteorology of the Polar Regions, 5) Southern Hemisphere Modelling, 6) Southern Hemisphere Aerology, 7) Clouds and Radiation, 8) GARP, 9) Meteorological-Biological Interactions at the Earth's Surface and, 10) General Sessions.

Contacts: Dr. S. Fritz, IAMAP President, National Environmental Satellite Service, NOAA, Federal Building 4, Suitland, Md. 20233 and Dr. W. L. Godson, IAMAP Secretary, Atmospheric Environment Service, Dept. of the Environment, 4905 Dufferin Street, Downsview, Ontario, Canada.

For details of individual symposia, names of convenors, instructions for submission of papers (deadline 1 August 1973) and general remarks, see page 372 of the April Bulletin.

\section{Call for Papers}

\section{International Tropical Meteorology Meeting, January 31-February 6, 1974, Nairobi, Kenya}

The American Meteorological Society will hold an International Tropical Meteorology Meeting in Nairobi, Kenya from January 31-February 6, 1974, cosponsored by the World Meteorological Organization. The East African Meteorological Department will be the host. The sessions will be held at the City Hall.

The program will concentrate on Meteorology of the Tropics, with special emphasis on Equatorial Latitude Meteorology and Applied Meteorology. Topics will include: 1) methods of observation in the tropics; 2) the role of the tropics in the general circulation; 3) forecastingnumerical weather prediction in the low latitudes and medium and long range forecasting for weather and drought; 4) cloud physics and weather modification; 5) applied meteorology-agrometeorology, hydrometeorology, and climatology.

The Program Chairmen are: U. S. Program Chairman, Prof. Richard J. Reed, and African Program Chairman, Dr. S. W. Gichuiya. 
Titles and 200 word abstracts should be received by the appropriate chairman no later than 15 July 1973. Papers originating from Africa should be mailed to Dr. S. W. Gichuiya, East African Meteorological Department, Headquarters, P.O. Box 30259, Nairobi, Kenya. Papers originating from the United States and all other countries except those in Africa should be mailed to Prof. Richard J. Reed, American Meteorological Society, 45 Beacon St., Boston, Mass. 02108, U.S.A. Speakers will be required to submit full papers $(2,4,6$, or 8 pages) by 15 October 1973. Instructions for preparing manuscripts will be sent with letters of acceptance.

\section{Call for Papers}

\section{Fifth Conference on Weather Forecasting and Analysis, March 4-8, 1974, St. Louis, Mo.}

The Fifth National Conference on Weather Forecasting and Analysis, sponsored by the American Meteorological Society, will be held at the Sheraton-Jefferson Hotel in St. Louis, Missouri, March 4 to 8, 1974. Local arrangements are under the Greater St. Louis Chapter of the AMS. The AMS Committee on Forecasting is assisting in arranging the technical program.

It is planned to have both invited and solicited papers on extratropical analysis and forecasting with special emphasis on short-range forecasting. Sessions will be held on the major topical areas: Mesoscale analysis and prediction, urban effects on air quality, use of numerical guidance in "weather" forecasting, applications of satellite imagery to weather forecasting, atmospheric predictability, and analysis and forecast problems related to transportation and industry. Also a general session is being scheduled for a limited number of papers outside the indicated areas to include topics on the role of the meteorologist in issuing public news releases on weather disasters of unique national significance. To the extent possible, the sessions will be aligned according to specific forecast parameters and time scales in an attempt to concentrate on those forecast techniques which are most applicable to the particular problem at hand.

A joint session is being arranged with the AMS Committee on Probability and Statistics on the Formulation, Dissemination, Understanding, and Use of Weather Forecasts. Another joint session will be held with the Committee on Aeronautical Meteorology on topics of special interest in aviation weather.

Titles and abstracts of 150-300 words must be received by the Program Committee prior to 1 October 1973 in order to meet program publication deadlines. Speakers should plan a 15-minute presentation with 5 minutes of discussion.

Mail all contributions to Professor Donald E. Martin, Program Chairman, Director of Meteorology, Saint Louis University, P.O. Box 8099, Laclede Station, St. Louis, Mo. 63156.

\section{International Livestock Environment Symposium of the ASAE, April 17-19, 1974, Lincoln, Nebr.}

The American Meteorological Society will cooperate in the International Livestock Environment Symposium sponsored by the American Society of Agricultural Engineers, April 17-19, 1974, Lincoln, Nebraska. The Symposium will be held at the Center for Continuing Education, University of Nebraska, Lincoln, Nebr.

The scope of the meeting will focus on environmental factors; climate, light, structural behavior, noise, disease, insects, air pollution and feeding practices. Livestock to be considered are aquatic, beef cattle, dairy cattle, poultry, sheep and swine.

Further information may be obtained from: American Society of Agricultural Engineers, 2950 Niles Road, St. Joseph, Mich. 49085 (tel.: 616-983-6521).
(Continued from announcements, page 468)

\section{Polar magnetic activity indices}

A new reference standard for geomagnetic activity, called the Auroral Electrojet (AE) Index, based on recorded geomagnetic variations at a number of observations around the auroral zone, has recently been compiled and published for the year 1970. The idea for the index was conceived several years ago by T. N. David, University of Alaska, and M. Sugiura, National Aeronautics and Space Administration. In an 18-month project led by Joe Haskell Allen, a geophysicist with the Boulder, Colo.-based National Geophysics and Solar-Terrestrial Data Center of the National Oceanic and Atmospheric Administration's Environmental Data Service, the $\mathrm{AE}$ indices were developed.

The AE indices provide a key to geomagnetic activity in polar regions not previously derivable from other magnetic index systems. They are also quantitatvie and can be tied back to the physical processes which produce the observed magnetic field variations. In addition, $\mathrm{AE}$ values can be derived for any given instant or from averaged variations in the magnetic field over selected time intervals.

Observations of magnetic effects of the auroral electrojet, an electric current that travels in the auroral zone ionosphere and is associated with geomagnetic storms and aurorae. Variations in this current cause variations in the earth's magnetic field. To record the data at the observatories, investigators use instruments called magnetographs, usually consisting of a magnet hanging from a quartz fiber or balanced on a knife-edge with a mirror attached to one end of the magnet. The instruments record the variations in the earth's magnetic field on rotating, paper-covered drums. From the resulting magnetograms, "digitized" values are derived from which the indices are compiled. Hand processing of the magnetograms is the most costly and timeconsuming aspect of the operation. During the 18-month project a group of high-school students from VocationalTechnical School in Boulder has been performing this aspect of the operation under a work-study program.

AE indices for 1970 from 2-1/2 min measurements gathered at 11 observatories throughout the polar regions have been compiled. Indices for other years are currently being derived. Magnetic tapes and microfilm copies of the $1970 \mathrm{AE}$ indices are available on request from NOAA's World Data Center A for Solar Terrestrial Physics, Boulder, Colo. 80302. 


\title{
METEOROLOGY OF THE SOUTHERN HEMISPHERE
}

\author{
by
}

\author{
H. van Loon, J. J. Taljaard
}

T. Sasamori, J. London, D. V. Hoyt

K. Labitzke, C. W. Newton

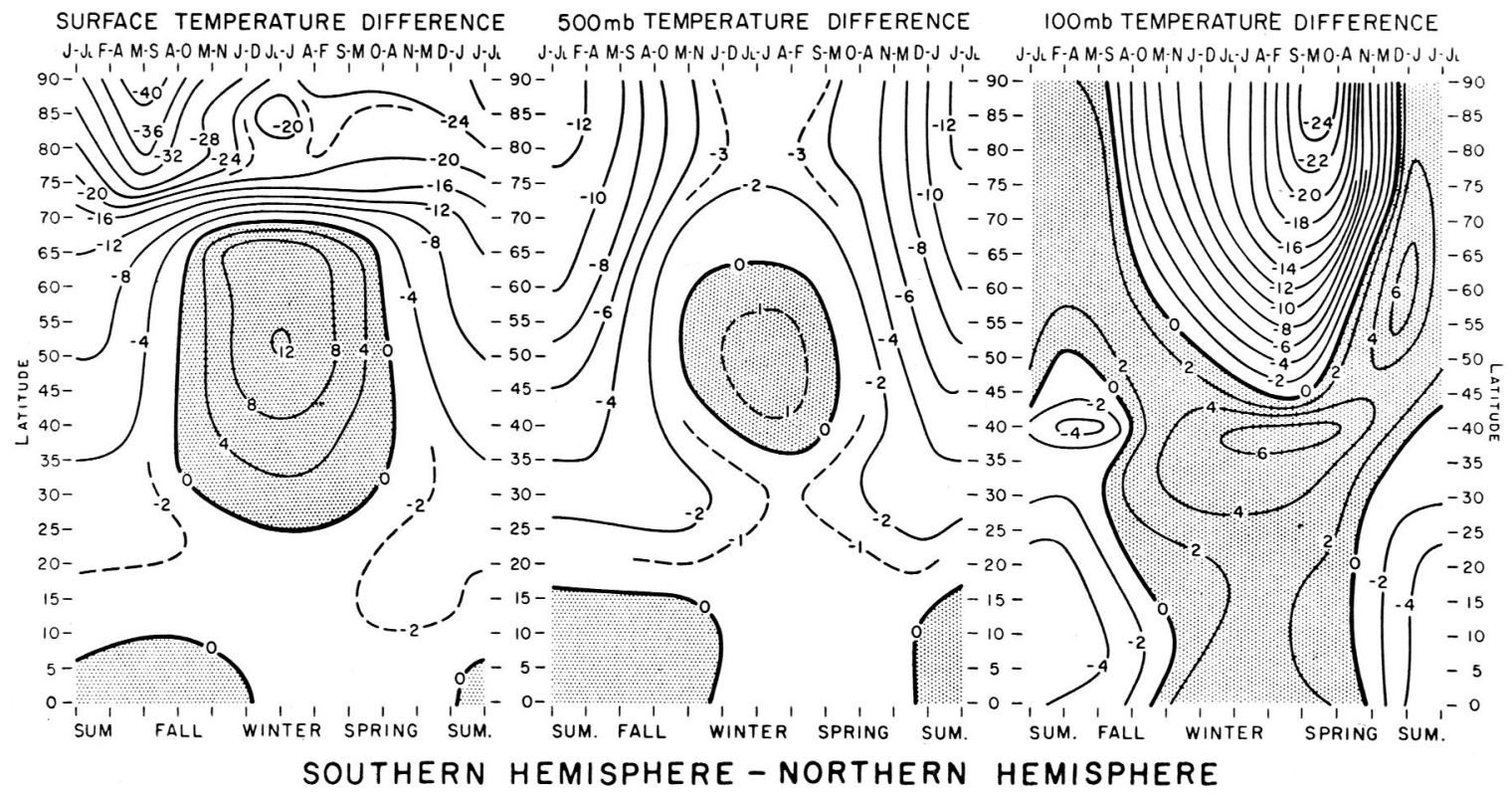

Meteorological Monographs

Vol. 13, No. 35

$\$ 12.00$ AMS Members
November 1972

263 pages (hard cover) $\$ 22.00$ non-members

Edited by

Chester W. Newton

National Center for Atmospheric Research

A timely, comprehensive, and eminently authoritative treatise of the meteorology of the Southern Hemisphere, which grew out of the global-scale data gathering during the International Geophysical Year, and which will be an indispensable aid in the development of realistic models of the global atmospheric circulation and in assessing the global spread of waste discharges from industrial activities.

The monograph contains contributions on the physical features of the Southern Hemisphere, its mean tropospheric and stratospheric structures and their seasonal variations, the synoptic systems, cloudiness and precipitation, the radiation budget, and the energy and momentum balance; all extended to or compared with the corresponding features in the Northern Hemisphere where this was feasible.

Send orders to

\section{American Meteorological Society}

45 Beacon Street, Boston, Massachusetts 02108 


\section{Standards information services}

The National Bureau of Standards' Standards Information Services provide up-to-date information on standards and standardization activities in the United States. The SIS maintains a reference collection of engineering and related standards which includes over 20,000 standards, specifications, test methods, codes, and recommended practices issued by more than 380 U.S. technical societies, professional organizations, and trade associations. The collection also includes specifications of state purchasing offices, standards and specifications of U.S. government agencies and of the major foreign and international standardizing bodies, and over 600 technical reference books, including directories, encyclopedias, guides, and manuals, and more than 70 periodicals and newsletters. SIS also acts as a referral activity by directing inquirers to appropriate standards-issuing organizations.

One way in which SIS performs its functions is through its KWIC index. The KWIC index is a computer-produced Key-Word-In-Context index which is capable of obtaining specific information on particular subjects.

Requests for lists of standards compiled by SIS, together with names of organizations where copies of the standards can be obtained, should be as specific as possible, and include all key words and terms necessary to locate the standards. By letter, persons interested in the service should write to: Standards Information Services, Room B147, Building 225, National Bureau of Standards, Washington, D.C. 20234. The telephone number is 301-921-2587.

\section{Meetings of interest}

2-4 July: An international Congress on "Methodologie d'Étude de l'Environnement Biométéorologique de l'Homme," methodology in the study of the biometeorological environment of man, is being jointly organized by L'Office Français de Recherches de Bioclimatologie and La Société Météorologique de France to be held in Paris at the Palais de l'UNESCO. Contact: Secretariat Conjoint des Journéés OFRB/SMF, 196, rue de l'Université-75 007, Paris, France.

2-6 July: A congress, "Le Soleil au Service de l'Homme," the Sun in the Service of Man, is being held in Paris, France, sponsored by L'International Solar Energy; La Cooperation Mediterranéenne Pour l'Energie Solaire; and L'Association Française l'Étude et le Developpement des Applications de l'Energie Solaire. Contact: Congress-Service, 1, rue JuleLefebvre, 75 009, Paris, France.

14-16 August: A Symposium on Instrumentation for Monitoring Air Quality will be held at the University of Colorado at Boulder, sponsored by the American Society for Testing and Materials' Committee D-22 on Methods of Sampling and Analysis of Atmospheres. Contact: American Society for Testing and Materials, 1916 Race St., Philadelphia, Pa. 19103.

20-22 August: An International Symposium on Applications of Computers and Operations Research to Problems of World Concern will be held in Washington, D.C., in cooperation with the U.S. Office of Naval Research. Contact: Mr. Ellison Burton, Office of Planning and Evaluation, U.S. Environmental Protection Agency, Washington, D.C.

27-30 August: The Vogel Centennial sponsored by the Society of Photographic Scientists and Engineers will be held at Windham College, Putney, Vt. Contact: Robert H. Wood, Executive Director SPSE, 1330 Massachusetts Ave., N.W., Washington, D.C. 20005.

1-12 September: The 9th Anual Conference of the Marine Technology Society will be held at the Sheraton-Park Hotel in Washington, D.C. The theme is "Marine Industries: Problems and Opportunities." Contact: Chairman, Program Committee, Marine Technology Society, 1730 M St., N.W., Suite 412, Washington, D.C. 20036.

4-10 October: A symposium on the Chemistry of Sea/Air Particulate Exchange Processes will be held at the University of Nice, France, sponsored by the Centre National de la Recherche Scientifique, the French Ministère de l'Environnement, and the Delegation Général à la Recherche Scientifique et Technique. The deadline for submission of abstracts is 1 July 1973. Contact: Secretary of the Sea/Air Symposium, Centre des Faibles Radioactivitiés-CNRS, 91190-Gif-surYvette, France.

\section{New publications}

Air pollution experiments for junior and senior high school science classes, second edition (APX, Donald C. Hunter and Henry C. Wohlers, compilors and editors, 1972, 128 pp., $\$ 1.50$, from Publications Department, Air Pollution Control Association, 4400 Fifth Avenue, Pittsburgh, Pa. 15213) contains 38 air pollution experiments.

Air pollution and public health (Charles H. Connolly, 1972, x +262 pp., n.p., paperbound, from The Dryden Press, a Division of Holt, Rinehart, and Winston Inc., 383 Madison Ave., New York, N.Y. 10017) is a summary of data about the health effects of air pollution, based on available literature and research, but it is not an exhaustive survey. It is an analysis prepared first as an in-house document for Chrysler Corporation.

Annual review of fluid mechanics, Volume 5, 1973 (Milton Van Dyke and Walter G. Vincenti, co-editors, and J. V. Wehausen, associate editor, 1973, 443 pp., il., $\$ 10.00$ in U.S. postpaid, $\$ 10.50$ elsewhere, hardbound, from Annual Reviews Inc., 4139 El Camino Way, Palo Alto, Calif. 94306) contains among other articles, the following: "Ludwig Prandtl in the Nineteen-Thirties" by Irmgard Flügge-Lotz and Wilhelm Flügge; "Longitudinal Dispersion and Turbulent Mixing in Open-Channel Flow" by Hugo B. Fischer; "Intermittency in Large-Scale Turbulent Flows" by Eric Mollo-Christensen; "Buoyant Plumes and Wakes" by James A. Fay; "Three-Dimensional Boundary Layers" by E. A. Eichelbrenner; and "Prandtl's Boundary-Layer Theory from the Viewpoint of a Mathematician” by Karl Nickel.

Buoyancy effects in fluids (Cambridge Monographs on Mechanics and Applied Mathematics, J. S. Turner, 1973, 367 pp., il., \$29.50 hardbound, from Cambridge University Press, American Branch, 32 East 57th St., New York, N.Y. 10022) gives a connected account of the various motions which can be driven or influenced by buoyancy forces in a stratified fluid, including internal waves, turbulent shearflows, and buoyant convection. The individual processes are described separately before being used to discuss the mechanisms which are responsible for vertical mixing and heat transfer in the atmosphere and ocean.

Climates of the states: Maine (C 55.221:17, S/N 0319-0016, 1972, revised, 26 pp., il., 35 cents, from Superintendent of 


\section{Preprint Volume}

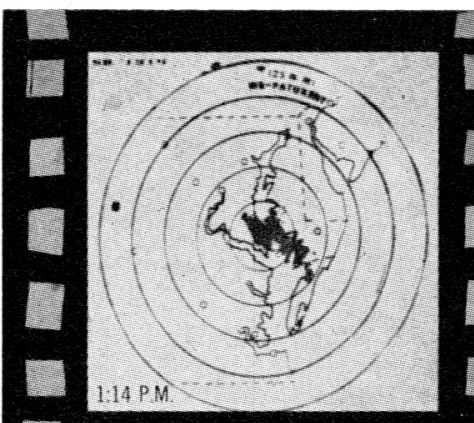

$=$
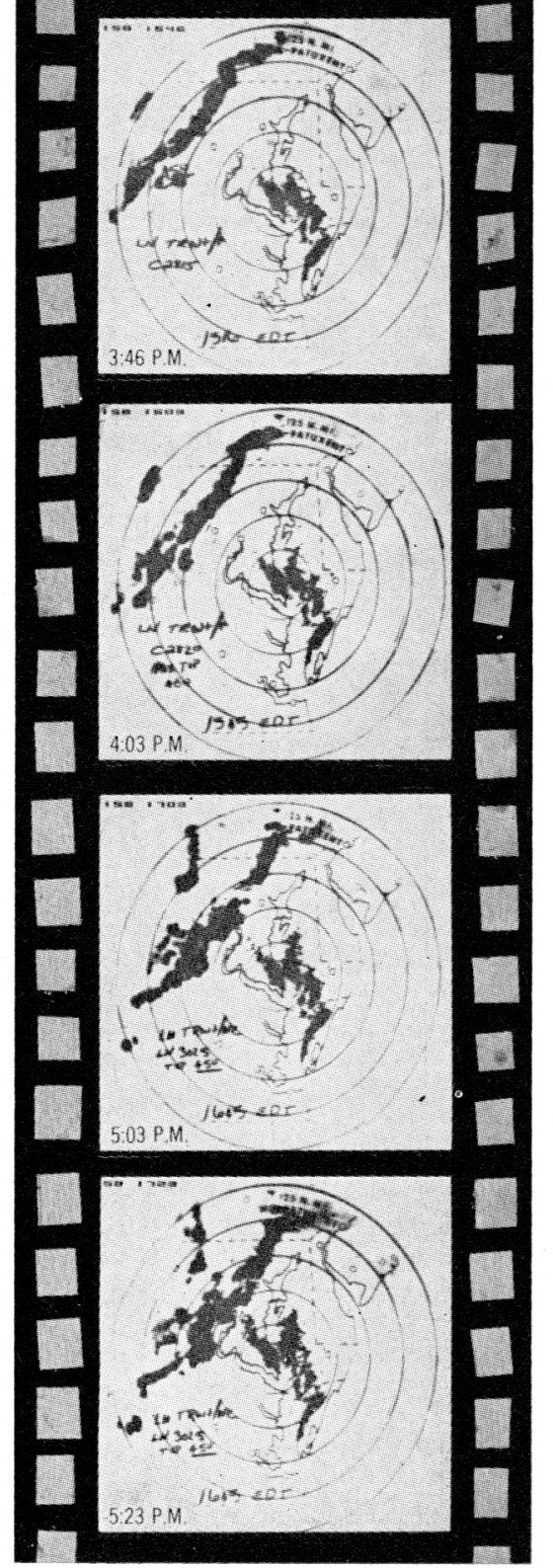

\section{I5th \\ RADAR \\ METEOROLOGY \\ CONFERENCE}

\author{
OCTOBER 10-12, 1972 CHAMPAIGN-URBANA, ILL. \\ AMERICAN METEOROLOGICAL SOCIETY
}

The preprint volume contains seventy-eight papers presented at the 15th Radar Meteorology Conference. The topics were chosen to place the greatest emphasis on the weather phenomena being investigated by radar techniques.

Most of the papers were contributed from the United States, however, papers from Australia, Canada, England, India, Japan, Republic of South Africa, Switzerland and West Germany are contained therein. Presentations are grouped under the following main sessions:

HAILSTORM \& SEVERE WEATHER RESEARCH I and II OPERATIONAL APPLICATIONS

RAINFALL MEASUREMENTS \& PRECIPITATION PHYSICS I and II

\section{RADAR DATA PROCESSING \& DISPLAY}

RADAR FUNDAMENTALS \& TECHNIQUES

ATMOSPHERIC STRUCTURE \& TURBULENCE I, II and III

Price: $\$ 20$

Pages: 378

\$15 AMS members

Send order and remittance to:

AMERICAN METEOROLOGICAL SOCIETY 45 Beacon Street

Boston, Massachusetts 02108 
Documents, U.S. Government Printing Office, Washington, D.C. 20402) is a detailed report on the climate of the listed state, including a physical description of each state, a study of the general climatic features, and a study of the relationship of the climate to the state's economy. A bibliography and weather maps and charts are included in each report.

Climates of the states: Minnesota (C 55.221:21, S/N 0319-0018, 1972, revised, 20 pp., il., 20 cents, from GPO, above) see description for Maine, above.

Climates of the states: New York (C 55.221:30, S/N 0319-0017, 1972, revised, 29 pp., il., 25 cents, from GPO, above) see description for Maine, above.

Cold fog dispersal operations at Orly Airport, Paris, France, winter 1970-71 (FAA-RD-72-123, R. Fabre, November 1972, 35 pp., $\$ 3.00$ paper copy, 95 cents microfiche, from National Technical Information Service, U.S. Department of Commerce, Springfield, Va. 22151) describes the operational results of a Ground-Based Propane Cold Fog Dispersal System at Orly Airport, France, during seven periods of cold fog which occurred during the winter of 1970-71.

Computer modeling of transportation-generated air pollution (PB-213-013, 'Transportation Systems Center, Cambridge, Mass., June 1972, 132 pp., \$5.45, from NTIS, above) surveys the states of the art of models and methods of atmospheric dispersion for air pollution, and reviews computer systems in use.

The earth: Our physical environment (William L. Donn, 1972, 620 pp., il., $\$ 13.95$ hardbound, from John Wiley \& Sons, Inc., Publishers, 605 Third Ave., New York, N.Y. 10016) emphasizes processes and principles instead of facts. It includes, among others, chapters on the atmosphere; the elements of the weather; planetary winds, weather and storms; the oceans: our marine environment; and climates of the past and present.

The edge of an unfamiliar world: A history of oceanography (Susan Schlee, 1973, 398 pp., il., \$10.95 hardbound, from E. P. Dutton, 201 Park Avenue South, New York, N.Y. 10003) is an attempt to trace the various motivations which have led scientists to study the sea and to describe the irregular progress they have made toward an understanding of oceanography during the past century and a quarter.

Encyclopedia of physics, Volume 4, Geophysics III/4 (S. Flügge, chief editor, K. Rawer, editor, 1972, 579 pp., 434 pp. in English, 163 pp. in French, DM 198 clothbound, from Springer-Verlag, 1 Berlin 33, Heidelberger Platz 3, BerlinWest Germany) contains the following articles: “The Earth's Magnetosphere" by H. Poeverlein; "The Earth's Radiation Belt" by W. N. Hess; "Variations rapides du champ magnétique terrestre" by E. Selzer; and "Waves and Resonances in Magneto-active Plasma" by V. L. Ginzburg and A. A. Ruhadze.

Federal funds for research, development and other scientific activities, fiscal years 1971, 1972, and 1973 (Vol. XXI, NSF 72317, National Science Foundation Division of Science Resources Studies, 1973, $\$ 2.75$, from GPO, above) shows a rising trend in federal research and development funding for the period covered. Data are based on those published in The Budget, 1973.

The federal ocean program $(\operatorname{Pr} 37.2: 0 \mathrm{c}, \mathrm{S} / \mathrm{N}$ 4106-0033, 1972, 121 pp., il., 70 cents, from GPO, above) is the annual report of the President to Congress on the nation's efforts to comprehend, conserve, and use the sea.

Fog and road traffic (PB-213 822, Transport and Road Research Laboratory, Crowthorne, 1972, 46 pp., \$3.75, from NTIS, above) discusses the effects of heavy fog on traffic and possibilities of reducing its hazards.

Fundamentals of wave propagation (Ivan Tolstoy, 1973, 352 pp., $\$ 16.00$ clothbound, from McGraw-Hill Book Company, 1221 Avenue of the Americas, New York, N.Y. 10020) presents the fundamental concepts of wave propagation, introduces the reader to the phenomena occurring in natural wave processes, and provides the basis for understanding how the applications of wave theory are used to study our environment.

Introduction to earth science (Henry Lepp, 1972, 550 pp., $\$ 11.95$ clothbound, from McGraw-Hill, above) uses an historical and investigative approach in an attempt to impart an appreciation of how we know about the earth rather than about what is known. The book treats the various earth environments together with the natural processes that produce environmental change.

Laboratory and field investigations in general ecology (Robert G. Rolan, 1973, 235 pp., \$5.95 paperbound, from the Macmillan Company, 866 Third Ave., New York, N.Y. 10022) is written for two different categories of students: those taking a laboratory in a freshman-sophomore level environmental-studies course for non-science majors and those taking a more advanced ecology course for biology majors. The manual is written so that the instructor can, by selection of certain sections, tailor the manual to the needs of a particular group of students.

Meteorological challenges: A history (D. P. McIntyre, editor, 1972, 338 pp., \$10.00 Canadian, hardbound, from Information Canada, Ottawa, Canada) contains analyses by 12 eminent scientists of the challenges to meteorology; how they have affected the discipline, and how the present challenges point the way to the future. Stories cover the range from challenges presented by atmospheric phenomena to the challenges of atmospheric prediction; from challenges presented by the interaction of man and his environment to the challenges of organizations.

Methods of air sampling and analysis (MAS Intersociety Committee for a Manual of Methods of Air Sampling and Analysis, 1972,500 pp., $\$ 12.50$, from APCA, above) is the first published volume of methods adopted as tentative by the Committee.

The following NASA Technical Reports are now available:

Atmospheric energetics as related to cyclogenesis over the eastern United States (NASA CR-2189, Philip Walter West, January 1973, 126 pp., $\$ 3.00$ paper copy, from NTIS, above) presents a method to investigate the atmospheric energy budget as related to cyclogenesis. Energy budget equations are developed that are shown to be advantageous because the individual terms represent basic physical processes which produce changes in atmospheric energy and the equations provide a means to study the interaction of the cyclone with the larger scales of motion. 


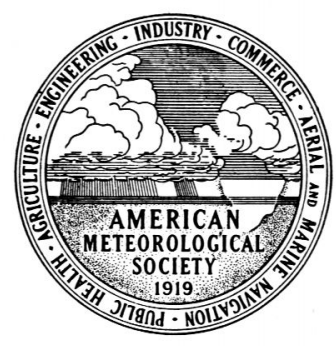

Undergraduate awards

\section{Undergraduate scholarships}

\section{Procedures and deadlines}

\section{American Meteorological Society}

announces

The Father James B. Macelwane Annual Awards

for original papers on meteorology,

The Howard T. Orville Scholarship in Meteorology, and

The Howard H. Hanks, Jr., Scholarship in Meteorology
The Father James B. Macelwane Annual Awards were established by the American Meteorological Society to honor the late Rev. James B. Macelwane, S. J., geophysicist and Dean of the Institute of Technology, Saint Louis University, until his death in 1956. Father Macelwane was a world renowned authority on seismology.

The purpose of these awards is to stimulate interest in meteorology among college students. All registered undergraduate students of a college or university in the Americas are eligible to participate. The only restriction is that no more than two students may enter contest papers from any one institution.

The Society encourages original student papers concerned with some phase of the atmospheric sciences. Award stipends are supported by Weather Corporation of America, private meteorological consultants, Saint Louis, Mo. A stipend of $\$ 150.00$ is awarded to the author of the paper deemed most worthy by the judging committee. Additionally, stipends of $\$ 100.00$ and $\$ 50.00$ are awarded to second and third place winners.

The Howard T. Orville Scholarship in Meteorology honors the late Howard T. Orville, Head of the Naval Aerological Service, 1940-50, when he retired as Captain, USN. He later served in key industrial posts and as Chairman of the Advisory Committee on Weather Control in 1953. A graduate of the U.S. Naval Academy, his service was marked by many commendations. Capt. Orville was President of the American Meteorological Society, 1948-49. Through a bequest from the estate of Howard T. Orville, the Society gives an annual scholarship of $\$ 300.00$.

The Howard H. Hanks, Jr., Scholarship in Meteorology honors the late Howard. H. Hanks, Jr. Mr. Hanks engaged for several years in applied and industrial meteorology until his very promising career was cut short by a plane crash. He was Vice President of Weather Corporation of America at the time of his death. A donation by William J. Hartnett, President of Weather Corporation of America, provides funds for the scholarship in the amount of $\$ 225.00$ per annum.

The Council of the Society has decided that the Orville Scholarship be given to a senior undergraduate meteorology major, and the Hanks Scholarship to a second student either in the senior or junior year.

The awarding of undergraduate scholarships in meteorology shall be based on academic excellence and achievement.

The candidate must be an undergraduate major in a meteorology department or other department actively engaged in work on some aspect of atmospheric science.

The candidate must intend to make atmospheric science his career and have completed at least 54 semester hours or their equivalent toward a Bachelor's degree.

The candidate applies by letter accompanied by a list of courses and grades in his major subject, and a listing of courses and grades in mathematics, physics, and other sciences. The candidate must be nominated by his major department and the nomination must be supported by a letter of recommendation from the department chairman or other designated department member reflecting the overall view of the department faculty.

The Macelwane Awards and the Orville and Hanks Scholarships are administered by the Society's Committee of Judges for Undergraduate Awards. Prof. Harold D. Orville, South Dakota School of Mines and Technology, is chairman of the committee, assisted by Dr. Richard A. Craig, Florida State University, and Prof. Donald R. Johnson, University of Wisconsin.

Papers for the Macelwane Awards and applications for the Orville and Hanks Scholarships must be received not later than July 15, in the headquarters of the American Meteorological Society, 45 Beacon Street, Boston, Mass. 02108. Announcement of awards and the scholarship recipients will be made each year at the Annual Meeting of the Society. 
The composite sequential clustering technique for analysis of multispectral scanner data (NASA CR-128999, M. Y. Su, October 1972, 61 pp., n.p., from NTIS, above) presents a new clustering technique consisting of two parts: 1) a sequential statistical clustering which is essentially a sequential variance analysis, and 2) a generalized K-means clustering.

The beta distribution: A statistical model for world cloud cover (NADA TM X-64714, Lee W. Falls, January 1973, 52 pp., n.p., from NTIS, above) attempts to determine an underlying theoretical statistical distribution to represent worldwide cloud cover.

A boundary layer approach to the analysis of atmospheric motion over a surface obstruction (NASA CR-2182, Walter Frost, J. R. Maus, and W. R. Simpson, January 1973, 153 pp., $\$ 3.00$ paper copy, from NTIS, above) proposes a boundary layer approach for the solution of the flow field induced over a two-dimensional surface obstruction, such as a building or other manmade structure.

Feasibility study of a zero-gravity (orbital) atmospheric cloud physics experiment laboratory (NASA CR-128998, A. B. Hollinden and L. R. Eaton, November 1972, 127 pp., n.p., from NTIS above) covers the first nine months (September 1971June 1972) of a feasibility and concepts study for a zerogravity (orbital) atmospheric cloud physics experiment laboratory. The primary objective was to define a set of cloud physics experiments which benefit from the near zerogravity environment of an orbiting spacecraft, identify merits of this environment relative to those of ground-based laboratory facilities, and identify conceptual approaches for the accomplishment of the experiments in an orbiting spacecraft.

An investigation of relationships between meso- and synoptic-scale phenomena (NASA CR-2030, James R. Scroggins, James E. Wood, Henry E. Fuelberg, and William L. Read, June 1972, 235 pp., $\$ 3.00$ paper copy, from NTIS, above) investigates relationships between meso- and synoptic-scale systems for four cases, using both statistical and semi-quantitative (synoptic) approaches.

An investigation of the Sutcliffe development theory (NASA CR-2192, Joseph Daniel Dushan, January 1973, 75 pp., $\$ 3.00$ paper copy, from NTIS, above) uses two case studies to test the Sutcliffe-Petterssen development theory for both cyclonic and anticyclonic development over the eastern United States.

High resolution power spectra of daily Zurich sunspot numbers (NASA TM X-64718, Harold C. Euler, Jr., January 1973, 23 pp., n.p., from NTIS, above) shows computations of high resolution power spectra of 77 years of Zurich daily sunspot numbers using various lags and data point intervals.

One hundred years of international cooperation in meteorology, 1873-1973: A historical review (WMO No. 345, IMOWMO Centenary, World Meteorological Organization, Howard Daniel, 1973, 53 pp., n.p., from UNIPUB, Box 433, New York, N.Y. 10016) is the story of the development of organized international cooperation in meteorology.
Plan for U.S. clear-air turbulence research in the Global Atmospheric Research Program (Report of the Panel on Clear Air Turbulence to the U.S. Committee for the GARP, Division of Physical Sciences, National Research Council, 1972, 36 pp., n.p., from U.S. Committee for the GARP, National Research Council,, 2101 Constitution Ave., N.W., Washington, D.C. 20418) recommends that additional federal support, primarily logistical, be provided for CAT studies already in planning, because of their importance to aviation safety and to understanding the effects of small-scale motions on large-scale dynamics of the atmosphere.

Proceedings of the full board meeting, June 1972, Ustaoset, Norway (International Council of Scientific Unions, 1973, 286 pp., $\$ 15.00$ plus postage, from ICSU Abstracting Board, Secretariat, 17 due Mirabeau, 75016 Paris, France) represents an up-to-date overview of the most recent developments in scientific and technical information worldwide.

Prohibiting military weather modification (S/N 5270-1623, 1972, 162 pp., \$1.25, from GPO, above) presents hearing held on 26 and 27 July 1972 before the Subcommittee on Oceans and International Environment of the Senate Committee on Foreign Relations, 92nd Congress, 2nd Session on Senate Resolution 281, which expresses the sense of the Senate that the U.S. government should seek the agreement of other governments to a proposed treaty prohibiting the use of any environmental or geophysical modification activity as a weapon of war, or the carrying out of any research or experimentation with respect thereto.

Serial atlas of the marine environment, Folio 21: Average monthly sea-water temperatures, Nova Scotia to Long Island, 1940-1959 (John B. Colton, Jr., and Ruth B. Stoddard, 1972, n.p., from American Geographical Society, Broadway at 156th St., New York, N.Y. 10032) provides a monthly summary of the major temperature features by means of maps of horizontal distribution and vertical profiles. It establishes temperature norms to which individual cruise data may be compared (author).

Serial atlas of the marine environment, Folio 22: Chemistry, primary productivity, and benthic algae of the Gulf of Mexico (S. Z. El-Sayed, W. M. Sackett, L. M. Jeffrey, A. D. Fredericks, R. P. Saunders, P. S. Conger, G. A. Fryxell, K. A. Steidinger, and S. A. Earle, $1972, \$ 12.00$ plus $\$ 1.00$ postage and handling, prepaid, from AGS, above) strives to summarize the knowledge of some aspects of the chemistry and biology of the Gulf, although it does not seek to be allencompassing.

Thermal fog dispersal manual (FAA-RD-72-138, compiled by the Fog dispersal and Meteorology Department, Transocean Air Lines, for the Navy Department by Direction of the Steering Committee for the Landing Aids Experiment Station, Arcata, Calif., 1972 reporting of January 1950 publication, 77 pp., n.p., from NTIS, above) describes the requirements and basic principles of design, construction, and maintenance of a thermal fog dispersal system.

Water and water pollution handbook, Volume 4 (Leonard L. Ciaccio, editor, 1973, 512 pp., il., \$29.50, from Marcel Dekker, Inc., 95 Madison Ave., New York, N.Y. 10016) is intended for anyone who needs to make measurements in the water environment. 
Weather forecasting for agriculture and industry (James A. Taylor, editor, 1973, 250 pp., $\$ 12.50$ hardbound, from Fairleigh Dickinson University Press, Box 421, Cranbury, N.J. 08512) is an analysis of the value and use of weather forecasts for the social and economic needs of the community. The 17 chapters discuss such questions as longer-range wea- ther forecasting in agricultural research, management and decision-making, an examination of its relevance to highway construction and the development of tourist activities, the prediction of urban climates resulting from building development, and the forecasting of demand for electricity.
(Continued from news and notes, page 450)

\section{Geomagnetic disturbances linked to weather changes}

For many years scientists have speculated that a dynamic link between intensifying upper air troughs and increasing geomagnetic activity exists. Now, evidence has been presented in the Journal of the Atmospheric Sciences (30, 135-140) by Dr. Walter Orr Roberts, President of the University Corporation for Atmospheric Research, and Roger H. Olson, Research Meteorologist in the National Oceanic and Atmospheric Administration's Environmental Data Service, confirming the earlier findings of investigators that a statistical relationship exists between the behavior of certain atmospheric features over the Gulf of Alaska and geomagnetic storms. The scientists only speculate as to a cause-and-effect mechanism linking trough development in the Gulf of Alaska with storms in the geomagnetic field which are marked by displays of aurorae; they suggest that additional research is necessary to develop more definitive and useful results.

Using analytic techniques used by previous investigators, but more refined, Roberts and Olson derived a representative geomagnetic activity index $\left(A_{p}\right)$ and a new trough index (the vorticity area index) which was determined objectively from computer-drawn lines of equal air particle rotation. A "key day" was defined as one on which $A_{p}$ equalled or exceeded 15 and rose to this value by a jump from the preceding day equal to or greater than the monthly mean $A_{p}$ value. An analysis of the trough index $\left(I_{t}\right)$ for the winter half-years of 1964-65, 1965-66, and 1970-71 showed that, on the average, 38 key troughs intensified more rapidly than 107 non-key troughs, results which confirmed earlier reported analyses. Analysis of data for the same periods using the vorticity area index of trough strength showed similar relations, further substantiating the earlier work. Also, it was found that the difference between key and non-key values was greater about two days after day 0 as compared with 4 and 5 days afterward, using the trough index. The level of geomagnetic and solar activity for these three years was considerably lower than for the years covered previously.

In another analysis covering seven winters, 1964-71, again using the vorticity methods of trough designation, 94 key troughs were compared to all other troughs (300) during the same period. The geomagnetic key troughs were already larger than the others on the day of first appearance; the difference increased in the two subsequent days in the Gulf of Alaska region. A second maximum difference was observed at day 7 , indicating a rejuvenation near the Atlantic Coast. Although cause and effect relations are speculative, the control may result from geomagnetic modulation of the radiation of heat to space from the relatively warm Gulf of Alaska during the winter. It may involve triggering of cirrus cloud formation, changes in ozone content, and possibly increased thunderstorm activity. Satellite infrared data indicating such changes for the 1970-71 winter season are being studied to test the idea of geomagnetic control of cirrus clouds, but further work is necessary. The analysis may provide an important clue to the physical process by which the vanishingly small direct energy inputs of geomagnetic activity in the lower stratosphere can cause large meteorological effecis.

It was concluded that these data independently confirm the reality of the association of geomagnetic disturbances with significant later intensifications in the $300-\mathrm{mb}$ circulation. The lag of time between the $A_{p}$ and the maximumvorticity development is ofien about 5-7 days, a period long enough to be of great interest to weather forecasters, because the effect may react to its maximum value near the limit of the lead time of conventional forecasting methods.

\section{Ice forecasting research}

Ice forecasting techniques currently under development by the National Oceanic and Atmospheric Administration's Lake Survey Center will be tested using data on water temperature collected from U.S. Steel Corporation ore carriers. The project, directed by Dr. Frank H. Quinn, Chief of the LCS's Lake Hydrology Branch, is being run in conjunction with the Great Lakes-St. Lawrence Seaway Navigation Season Extension Demonstration Program.

Because LCS research vessels were not built to withstand severe weather and ice conditions of the lakes in winter, LSC requested and was granted permission by U.S. Steel to work from their vessels, which are operating during the extended navigation season. Researchers are using expendable bathythermograph systems consisting of a small recorder and expendable temperature sensing probes. Individual probes are released at selected intervals along the ship's track and are expended after completing the recording of a temperature profile. Temperature measurements before and during ice formation were made during five or six trips between the Soo Locks and Two Harbors, Minnesota.

Part of the goal of the Lake Survey Center is to extend the navigation season on the Great Lakes through the actual study of the ice itself. The center's overall program is divided into three distinct parts: 1) maintaining a network of ice observation posts which report on ice formation, thickness, and related matters; 2) field operations which include collection, preparation, and analysis of ice samples taken from a variety of locations; and 3) aerial observations made regularly which provide information on the extent of the ice cover and types of ice observed.

To implement its goals the LSC has set up a network of 25 ice stations, in addition to 10 in areas critical for shippers, which will observe ice conditions. LSC scientists planned to visit an additional 21 sites this winter to collect ice samples for laboratory analysis. At the same time temperature measurements were made from permanent stations and ships operating during the winter in Lake Superior. 
With accumulated data the scientists hope to be able to forecast ice freeze-up and break-up in the future.

One phase of this work is being done in support of the International Field Year for the Great Lakes, a part of the International Hydrological Decade, which it is hoped will provide data for the preservation and management of the Great Lakes.

\section{Tornado detectors deployed by NOAA}

Experimental deployment of electronic "tornado detectors" by the National Oceanic and Atmospheric Administration is continuing during the 1973 tornado season. Favorable results were obtained during the 1972 season experiment, conducted by the Wave Propagation Laboratory, a component of NOAA's Boulder-based Environmental Research Laboratories, in conjunction with NOAA's National Weather Service and National Severe Storms Forecast Center, Kansas City, Mo.

The electronic tornado sensors are receivers tuned to a frequency of $3.16 \mathrm{mHz}$ for two threshold levels corresponding to signal amplitudes expected at ranges out to $30 \mathrm{~km}$ and $70 \mathrm{~km}$ from the instrument. According to William L. Taylor, project leader for WPL, the instruments measure an electromagnetic signature of processes in cloud systems where tornadoes are likely to occur, rather than the presence of tornadoes themselves. Based on numerous observations of electrical phenomena reported in connection with tornadic thunderstorms and with data obtained experimentally over the past few years, the experiments represent an attempt to measure the interactions between atmospheric events and various regions of the electromagnetic energy spectrum.

Using earlier experimental results, scientists tuned the instruments installed in tornado alley in 1972 to a region of the spectrum where certain types of storms generate highrate bursts of electromagnetic energy. Moderate thunderstorms, for example, generate an average burst rate of about $3 \mathrm{~min}^{-1}$, while severe storms with related hail and wind damage produce about 10 bursts $\mathrm{min}^{-1}$, severe storms associated with funnel clouds, about 13 bursts $\mathrm{min}^{-1}$, and severe storms that produced tornadoes, about 20 bursts $\mathrm{min}^{-1}$. Fifteen field units were utilized during the 1972 season, which logged a total of more than 66,000 operating hours, with outages of about 3000 hrs caused by interference and equipment malfunction.

Preliminary data analysis indicates there were 542 electromagnetic responses by the equipment during the 1972 season, which were correlated with severe Weather Reports from NSSFC. Equipment responses which appeared to correspond to the severe storm activity within $70 \mathrm{~km}$ of the instrument were examined to measure whether, and how well, the method worked. Equipment responses showed 41 tornadoes, 30 funnel clouds, 54 hail storms, 60 windstorms, and 507 local thunderstorms. Assuming that a burst-rate of more than 20 bursts $\mathrm{min}^{-1}$ indicated tornadic activity, the instrument would have warned against $73 \%$ of the tornadoes, have indicated about $40 \%$ of the funnel cloud storms as tornadic, and $27 \%$ of the hail and windstorms as possibly tornadic. Only $6.5 \%$ of the local thunderstorms would have produced false alarms, Taylor indicated, although he emphasized that these results are preliminary.

During the 1973 tornado season instrument have been installed at NWS stations in Amarillo, Lubbock, and Fort Worth, Tex.; Oklahoma City and Tulsa, Okla.; Little Rock,

\section{PROCEEDINGS SUMMER COMPUTER SIMULATION CONFERENCES}

Applications of continuous system simulation in the Physical Sciences, Chemical Sciences, Earth Sciences, Life Sciences, and Social Sciences

1972: Proceedings 1972 SCSC

June 14-16, 1972, San Diego, Calif.

Sponsored by AIAA/AIChE/AMS/ISA/SCi/ SHARE

Approx. 1500 pages, two volumes, paper. $\$ 20$ set.

1971 : Proceedings 1971 SCSC

July 19-21, 1971, Boston, Mass.

Sponsored by ACM/AIAA/AIChE/IEEE/ ISA/SHARE/SCi

1323 pages, two volumes, paper. $\$ 20$ set.

1970 : Proceedings 1970 SCSC

June 10-12, 1970, Denver, Colo.

Sponsored by ACM/SHARE/SCi

1218 pages, two volumes, paper. $\$ 15$ set.

1969: Proceedings of the Conference on Applications of Continuous System Simulation Languages

June 30-July 1, 1969, San Francisco, Calif. Sponsored by ACM/IEEE/SHARE/SCi 256 pages, paper. $\$ 10$.

SCSC Proceedings may be ordered from: AFIPS Press

210 Summit Avenue

Montvale, New Jersey 07645

Ark.; Memphis, Tenn.; Jackson, Miss.; Tampa, Fla.; Grand Island, Nebr.; Des Moines, Iowa; Topeka and Wichita, Kans.; and Springfield and St. Louis, Mo. These sites lie along "tornado alley," the curved seasonal path followed by the center of maximum frequency of U.S. tornadoes. The major difference in this year's deployment of instruments arises from the major disadvantage reported by weathermen from the 1972 experiment. Then, each instrument had to be interrogated by telephone by meteorologists, at a time when these meteorologists had least time for interrogation-usually when a severe storm was bearing down on their area of responsibility. This year, the instruments will operate continuously, and can be easily monitored by weather forecasters when conditions warrant.

\section{Meteorological mast in The Netherlands}

A new $213 \mathrm{~m}$ high meteorological mast was recently erected near Cabauw, approximately $21 \mathrm{~km}$ southwest of Utrecht, The Netherlands. The mast is situated in an area of flat countryside, which is rather homogeneous on a large scale over distances ranging between $10 \mathrm{~km}$ to the east and $25 \mathrm{~km}$ to the west. At the surface the free fetch is greater than $400 \mathrm{~m}$ in all directions except to the east.

The mast was erected for the use of the Royal Netherlands Meteorological Institute so that the Institute could extend its investigations of diffusion and wind structure at an $80-\mathrm{m}$ mast in Vlaardingen (see Boundary-Layer Meteorology, 1, 5-17) to above the surface layer. Flexibility in experimental planning was achieved by providing a series of generalpurpose plugs at various points along the mast on which 
unspecified instruments can be placed, and then linked to signal processing equipment at the foot of the mast.

The mast consists of a cylinder with a diameter of $2 \mathrm{~m}$, with 9-m booms placed in three directions at levels of 20, $40,60,80,100,120,140,160,180$, and $200 \mathrm{~m}$. These booms can be swivelled upwards hydraulically for the servicing of instruments. A small elevator runs inside the mast. At the base of the mast an octagonal instrument building, 4-m high, with an extreme radium of $9 \mathrm{~m}$ was built. Measurements below $20 \mathrm{~m}$ are made at $60-\mathrm{m}$ horizontal distance from the mast's foot. At the end of 1972 the instrumentation infrastructure was completed.

At the present time a pilot study is in progress. It consists of the a) measurement of horizontal wind speed and direction and of absolute temperature at 10, 80, and 200 $\mathrm{m}$; b) measurement of temperature differences between the levels $2,10,20,40,80,120,160$, and $200 \mathrm{~m}$; c) measurement of relative humidity at 2,87 , and $207 \mathrm{~m}$, and of precipitation at $0.4 \mathrm{~m}$; d) measurement of light transmission over a $10-\mathrm{m}$ horizontal path at $1,5,20,40,60,100,140$, and $180 \mathrm{~m}$, for fog investigations; e) measurement of global radiation at 2 and $214 \mathrm{~m}$, and of radiation balance at $2 \mathrm{~m}$; and f) measurement of $\mathrm{SO}_{2}$ concentration at 3, 107, and $207 \mathrm{~m}$.

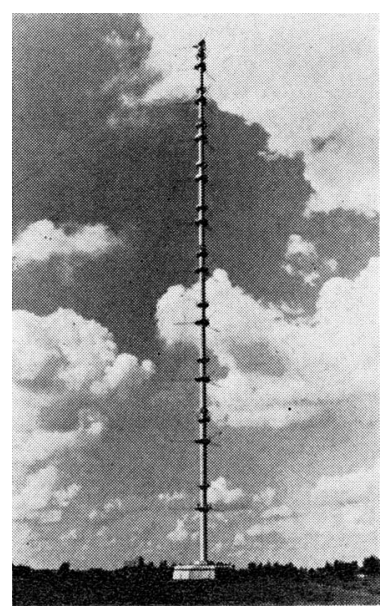

The measurements being made under categories a) and b) are averaged over 120 -sec periods and punched on paper tape until digital magnetic recording equipment is completed. The remaining measurements are recorded on charts or integrating printers, with the exception of the $\mathrm{SO}_{2}$ data, which are relayed by telephone to the air pollution network center at the State Institute for Public Health (R.I.V.), Bilthoven. The research program is under the direction of Prof. Dr. F. H. Schmidt, Koninklijk Nederlands Meteorologisch Instituut, De Bilt, The Netherlands.

\section{Deep-sea tide and current meter}

The National Oceanic and Atmospheric Administration's Engineering Development Laboratory of the National Ocean Survey has developed a free-falling, deep-sea instrument system which can automatically measure bottom tides and currents for up to six months. Last May the deep-sea, tide-gage and current-meter system was dropped to the ocean floor in about $335 \mathrm{~m}$ of water about $161 \mathrm{~km}$ southeast of San Juan, Puerto Rico. On 9 November 1973 it popped to the surface at an acoustic signal from the NOAA Ship Discoverer. Developed over a period of 18 months at a cost of approximately $\$ 50,000$, the system was pronounced operational when the instruments were recovered and their data were found to be complete.

The development, deployment, and retrieval of the systems were handled by the Engineering Development Lab's Miami-based Ocean Engineering Branch under the supervision of Jack Falkenhof. The measuring instruments consist of a tide gage and current meter, with an acoustic release system that allows the anchor base to remain at the bottom

\section{METEOROLOGISTS}

Project definition and management of field meteorological and ambient air quality measurement program, reduction and evaluation of data, calculation and evaluation of stack effluent and cooling tower dispersion patterns; preparation of environmental restraints. Familiarity with atmospheric transport and diffusion models desirable.

\section{OPPORTUNITIES}

NUS (formerly Nuclear Utility Services, Inc.) is an organization of consulting engineers and scientists engaged primarily in the energy and environmental fields.

In slightly more than a decade, we've grown to become one of the largest independent consultants in these key areas and our expertise has gained national and international recognition.

We're headquartered in Rockville, Maryland, 15 miles north of Washington, D. C., with convenient living close to work, outstanding academic institutions and easy access to the Capital.

For the above position, send resume to Nancy Root, Personnel Administrator.

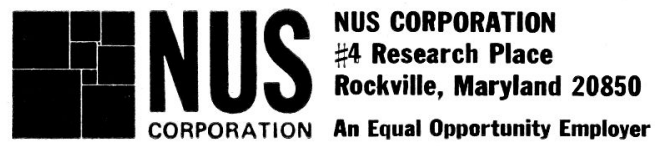

and the instrument package to separate and come to the surface at a signal from the ship. The current meter is located about $30.5 \mathrm{~m}$ from the sea floor bottom, supported by a flotation unit and is connected to the system by a cable.

\section{Ecology action notes}

While attempting to gather plankton during the Marine Resources Monitoring, Assessment and Prediction (MARMAP) program, scientists from the National Oceanic and Atmospheric Administration found evidence that the presence of oil globules and plastic debris was far more widely distributed than previously suspected. Massive proportions of the pollutants contaminate nearly $700,000 \mathrm{mi}^{2}$ of blue water from Cape Cod to the Caribbean Sea; they are now a part of the habitat of innumerable newborn blue marlin, tuna, bluefish, and other prized game and commercial species. On cruises during July and August 1972 the scientists experienced difficulty with plankton-collecting nets from fouling by tar balls, which ranged from grain- to fist-size and appeared to have been formed from bunker oil jettisoned from ships.

Subsequent laboratory analyses revealed that more than half the plankton samples collected from surface waters were oil-contaminated. Scientists estimated that contamination covered $50 \%$ of the survey area along the East Coast Continental Shelf; $80 \%$ from the Caribbean to the Gulf of Mexico; and $90 \%$ of the Antillean Chain.

Plastic contaminants, though not as widespread as the tar balls, were found in all survey regions. Distribution 
analysis showed a $20 \%$ occurrence in the vicinity of the Caribbean Sea, and a $50 \%$ occurrence in the Antillean Chain and the Continental Shelf between Cape Cod and Florida. MARMAP research characterized the plastic debris occurrence in the open sea as unexpected; until recently distribution was thought to be chiefly in inshore waters.

Despite the small size of the plastic particles, scientists believe that they may threaten the survival of many of the minuscule larval fish that consume them. It was cautioned, however, that MARMAP findings are not, in themselves, conclusive, that the total environmental effect of these widespread contaminants in the ocean remains to be evaluated.

Technology originally developed by the National Aeronautics and Space Administration to protect nuclear rocket nozzles from vibration is currently being applied to the development of an inexpensive, simple method to modify automobile engines to reduce exhaust fumes significantly. The project was initiated at NASA's Lewis Research Center three years ago when the Environmental Protection Agency asked NASA to study materials for an automotive thermal reactor, a device which would complete combustion of unburned gasoline, and convert $\mathrm{CO}$ and hydrocarbons into $\mathrm{CO}_{2}$ and $\mathrm{H}_{2} \mathrm{O}$. NASA engineers have successfully tested materials such as silicon carbide and other ceramics as liners for the hot combustion chamber of the thermal reactor system. Although these materials do not fail by oxidation as do metals, they are more easily damaged by vibration and road shock than metals. To allay this difficulty, investigators have cushioned the brittle materials with thin corregated metal springs between the ceramic liner and the metal reactor housing.

Full-scale testing is being performed on the two most promising types of ceramic material. Full size reactors were tested under NASA contrast by Teledyne-Continental Motors, Inc., of Muskegon, Mich. The endurance cycle included variations which simulated normal driving conditions. Silicon carbide reactors were successfully operated for the life of the engine.

\title{
A NEW AMS PUBLICATION
}

\section{WORKSHOP ON MICROMETEOROLOGY}

\author{
Duane A. Haugen, Editor \\ On the mechanics of atmospheric turbulence-Niels E. BusCH \\ Turbulent transfer in the atmospheric surface layer-J. A. Businger \\ On surface-layer turbulence-JoHN C. WYNGAARD \\ Tower micrometeorology-Hans A. Panofsky \\ Similarity laws and scale relations in planetary boundary layers $-\mathrm{H}$. TENNEkES \\ Numerical modeling of the planetary boundary layer-M. A. EsToouE \\ Three-dimensional modeling of the planetary boundary layer-JAMEs W. DEARDorFF \\ Construction of a dynamic model of the production of atmospheric turbulence \\ and the dispersal of atmospheric pollutants-Coleman DUP. DonalDson
}

An intensive and comprehensive review of current meteorological knowledge of the structure and dynamics of atmospheric boundary layers. The volume, consisting of revised versions of the lecture notes prepared for the August 1972, AMS-sponsored workshop, is an indispensable reference for all concerned with the properties and effects of surface layer turbulence. $392 \mathrm{pp}$.

AMS Members $\$ 24$, Nonmembers $\$ 30$

Member price will apply for classroom use (bulk order 12 or more copies)

Send orders and remittance to:

American Meteorological Society, 45 Beacon Street, Boston, Massachusetts 02108 